\title{
Comparative Anatomical Studies on Three Endemic Ononis L. (Leguminosae) Species Growing in Turkey
}

\section{Türkiye'de Yetişen Üç Endemik Ononis L. (Leguminosae) Türü Üzerinde Karşılaştırmalı Anatomik Çalışmalar}

\author{
Ayşe BALDEMiR ${ }^{1 *}$, Maksut COŞKUN² \\ ${ }^{1}$ Erciyes University, Faculty of Pharmacy, Department of Pharmaceutical Botany, Kayseri, Turkey \\ ${ }^{2}$ Ankara University, Faculty of Pharmacy, Department of Pharmaceutical Botany, Ankara, Turkey
}

\begin{abstract}
Objectives: The leaf and stem anatomical characteristics of three endemic Ononis L. (Leguminosae) species were studied for the first time for the evaluated in terms of systematic of similarities and differences in these taxa.

Materials and Methods: Ononis sessilifolia Bornm., Ononis basiadnata Hub.-Mor. and Ononis macrosperma Hub.-Mor. were collected from different provinces of Turkey. In this anatomical study, transversal and superficial sections from the leaves and transversal sections from stems of the species were taken and examined by appropriate reagends. Illustrations were obtained by using an Olympus U-DA 2K 17149 drawing tube attached to an Olympus BX50 microscope. The microphotographs were taken by a Leica DM 4000 B microscope.

Results: O. macrosperma is bifacial leaf, the others are monofacial leaf. The leaf of $O$. basiadnata has eglandular trihomes. If the anatomical similarities between species are to be listed, Rubiaceae type stoma was observed in all three species and solitary crystals were found in stem and leaf sections.
\end{abstract}

Conclusion: Anatomical characteristics, such as mesophyll structure, transmission bundles and crystal structures, may contribute to the taxonomy of Ononis species for future work.

Key words: Ononis, leaf and stem anatomy, endemic, Leguminosae, Turkey

öz

Amaç: Üç endemik Ononis L. (Leguminosae) türünün yaprak ve gövde anatomik özellikleri, bu taksonlarda benzerliklerin ve farklılıların sistematik olarak değerlendirilmesi için ilk kez çalıșılmıştır.

Gereç ve Yöntemler: Ononis sessilifolia Bornm., Ononis basiadnata Hub.-Mor. ve Ononis macrosperma Hub.-Mor. türleri Türkiye'nin farklı illerinden toplanmıştır. Bu anatomik çalışmada, türlerin gövdelerinden enine, yapraklardan ise enine ve yüzeysel alınmış ve uygun reaktiflerle incelenmiştir. Çizimler Olympus BX50 mikroskoba bağlı bir Olympus U-DA 2K 17149 çizim tüpü kullanılarak yapılmıştır. Mikrofotoğraflar Leica DM 4000 B mikroskobu ile çekilmiștir.

Bulgular: O. macrosperma bifasiyal yaprak, diğerleri monofasiyal yapraktır. O. basiadnata'nın yaprağı örtü tüyüne sahiptir. Türler arasındaki anatomik benzerlikler sıralanacak olursa, her üç türde Rubiaceae türü stoma ve gövde ve yaprak kesitlerinde ise tekli kristaller görülmüștür.

Sonuç: Mezofil yapısı, iletim demetleri ve kristal yapıları gibi anatomik özellikler, gelecekteki çalışmalar için Ononis türlerinin taksonomisine katkıda bulunabilir.

Anahtar kelimeler: Ononis, yaprak ve gövde anatomisi, endemik, Leguminosae, Türkiye 


\section{INTRODUCTION}

Leguminosae, third largest family of flowering plants, is cosmopolitan family and absent only from Antarctica. Many species in this family are cultivated for food in the different regions of worldwide, such as beans, peas, peanuts, and soybean. ${ }^{1,2}$ The genus Ononis L. belonging to the Leguminosae is represented by 75 taxa worldwide. The genus have 17 species of which 4 taxons are endemic in Turkey. ${ }^{3-5}$ In different regions of our country, the species of Ononis are used in folk medicine to diuretic, antiseptic and antimicrobial effects. ${ }^{6}$ In addition, the aerial part of Ononis arvensis L. has been used in traditional medicine to treat urinary tract infections and skin diseases. In the literature, there have been a few anatomical and morphological studies on some Ononis species. ${ }^{7-12}$ Anatomical investigations are of great importance in the identification of medicinal plants. ${ }^{13}$ Leaf epidermal studies are useful in determining their anatomical characteristics thus helping in the evaluation of a taxonomic relationship according to similarities and differences between species. ${ }^{14}$

In this study, the anatomical and morphological properties of three endemic Ononis species (Ononis sessilifolia Bornm., Ononis basiadnata Hub. - Mor. and Ononis macrosperma Hub. - Mor.) were studied comparatively. In addition, new and extended findings on three species of Ononis are presented in comparison with the definitions given in Metcalfe and Chalk ${ }^{15}$ and anatomical structures of the other Ononis species.

\section{EXPERIMENTAL}

\section{Plant materials}

Plant materials were gathered from the localities indicated in Table 1. Voucher specimens are deposited in the Herbarium of the Faculty of Pharmacy at the University of Ankara, Turkey (AEF).

Table 1. Locations and herbarium numbers of the studied Ononis species

\begin{tabular}{|c|c|c|}
\hline Species & Locations & $\begin{array}{l}\text { Herbarium } \\
\text { number }\end{array}$ \\
\hline $\begin{array}{l}\text { Ononis } \\
\text { sessilifolia }\end{array}$ & $\begin{array}{l}\text { C5 Niğde: Çamardı, Demirkazık, } \\
\text { Narpızlı plateau, channel } \\
\text { around, rocky slopes, s.l. } 2073 \\
\text { m, 13.06.2007, Ayşe and Şükrü } \\
\text { Baldemir }\end{array}$ & (AEF 23979) \\
\hline $\begin{array}{l}\text { Ononis } \\
\text { basiadnata }\end{array}$ & $\begin{array}{l}\text { C4 İçel: Gülnar-Mut road, exit of } \\
\text { Gülnar, fields, among maquis, s.l. } \\
1140 \text { m. 08.06.2007, Ayşe and } \\
\text { Şükrü Baldemir }\end{array}$ & (AEF 23968) \\
\hline $\begin{array}{l}\text { Ononis } \\
\text { macrosperma }\end{array}$ & $\begin{array}{l}\text { C2 Antalya: Elmalı, Çığlıkara, } \\
\text { entrance of Sinekçibeli, rocky } \\
\text { slopes, Cedrus libani forest, s.l. } \\
1684 \text { m. 29.5.2008, Ayşe and Şükrü } \\
\text { Baldemir }\end{array}$ & (AEF 24698) \\
\hline
\end{tabular}

\section{Anatomical studies}

The microscopical studies were carried out on material (aerial parts of Ononis species) in $70 \%$ alcohol. Free hand sections were taken, stained and mounted in Sartur reagent ${ }^{16}$ and chloralhydrate solution.

Anatomical drawings of the transversal and superficial sections were sketched using an Olympus U-DA 2K 17149 drawing tube attached to an Olympus BX50 microscope. The microphotographs were taken by a Leica DM 4000 B microscope and some of them were composed by the Adobe Photoshop 7.0 program.

\section{RESULTS AND DISCUSSION}

\section{Anatomical studies}

\section{Leaf anatomy of $O$. sessilifolia}

\section{Cross section of leaf blade}

The leaf is monofacial. The upper epidermis cells are square or rectangular-shaped, and are single-layered with anticlinal walls. Underneath the epidermis there are generally two layers of palisade parenchyma but sometimes there is a singlelayer. The spongy parenchyma with 2-3 layers is formed of thin walled, isodiametric parenchymatous cells with few intercellular spaces. Glandular hairs with a multicellular stalk and a multicellular head are observed. The lower epidermis cells are covered with a thin cuticle. Stomata occur on both sides of the leaves (Figure 1).

\section{Cross section of the midrib}

The lower epidermis cells are smaller than the upper ones and are covered with a thin cuticle. Underneath the epidermis there are generally two layers of palisade parenchyma but sometimes there is a single-layer. Sclerenchyma cells generally form crescent-shaped groups surrounding phloem (the thin-walled irregular constellation of small cells) and the xylem (wider vessels and tracheids) is underneath it. Solitary crystals which are very variable in size and shape (styloids) are characteristically observed and frequently form a sheath along the outer boundary of the pericyclic sclerenchyma (Figure 1).

\section{Surface of the lower and upper epidermis}

The lower epidermal cells are similar to those in the upper epidermis in point of small rectangular shape and thin-walled structure. Rubiaceae type stomata (each stoma is surrounded by 2 or more subsidiary cells) have 3-4 subsidiary cells. There are glandular hairs on both the upper and lower epidermis (Figure 1).

\section{Leaf anatomy of 0 . basiadnata}

\section{Cross section of leaf blade}

The leaf is monofacial. The upper epidermis cells are rectangular-shaped, single-layered with thin anticlinal walls, and have a smooth cuticle. Similar to O. sessilifolia, underneath the epidermis there are generally two layers of palisade parenchyma but sometimes there is a single-layer. Spongy cells with 2-3 layers, thin walled and isodiametric 
parenchymatous cells, are irregulary arranged. Glandular hairs is more dense with respect to $O$. sessilifolia can be classified into two types: those, with a multicellular stalk (1-4 row cells) and a multicellular glandular (1-5 row cells) head and those with a multicellular stalk and an unicellular glandular head. Also, eglandular hairs are observed densely (Figure 2 ).

\section{Cross section of the midrib (the central vein of a leaf)}

The lower epidermis cells are square or rectangular shape and thin walled structure, smaller than the upper ones and are covered with a thin cuticle. Sclerenchyma cells generally form crescent-shaped groups surrounding phloem which thinwalled irregular constellation of small cells and the xylem with

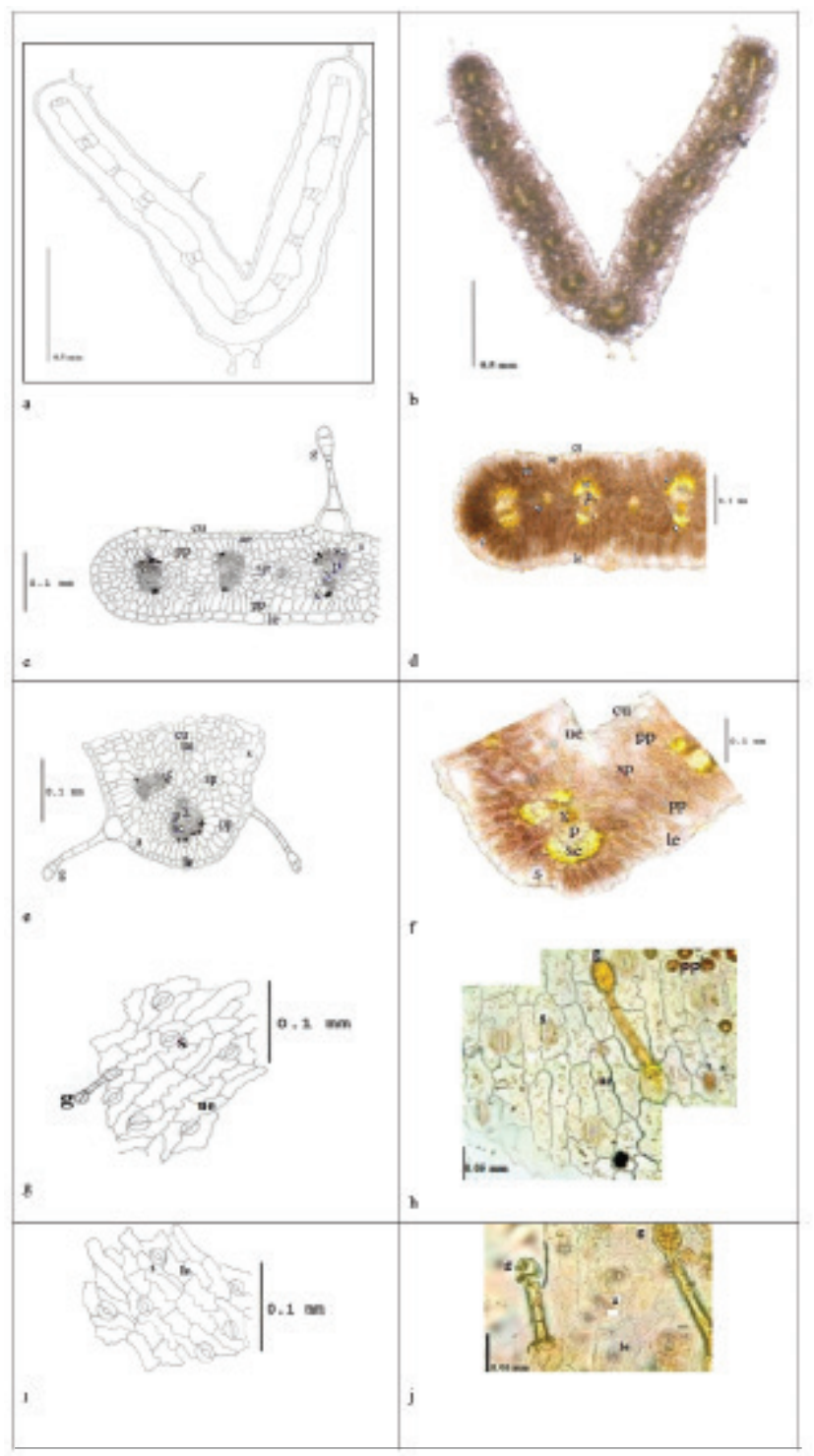

Figure 1. O. sessilifolia, a,b) Schematic drawing of the transverse section of the leaf and photo; c,d) Schematic drawing of transverse section of leaf blade and photo; e,f) Schematic drawing of transverse section of midrib and photo; g,h) Drawing of upper surface view of leaf and photo; I,j) Drawing of lower surface view of leaf and photo

cu: Cuticle, g: Glandular hair, ue: Upper epidermis, c: Crystal, pp: Palisade parenchyma, sp: Spongy parenchyma, sc: Sclerenchyma, p: Phloem, x: Xylem, s: Stomata, le: Lower epidermis vessels and tracheids is underneath it. Unlike 0 . sessilifolia, solitary crystals are also abundantly present in the parenchyma cells of $O$. basiadnata species. Similarly to $O$. sessilifolia, crystals are characteristically observed in the pericyclic sclerenchyma cells. Also, these crystals have been found in the mesophyll (Figure 2).

\section{Surface of the lower and upper epidermis}

Glandular and eglandular hairs are observed to densely cover both the upper and lower epidermis. The stomata have 3-4 subsidiary cells which is Rubiaceae type (Figure 2).

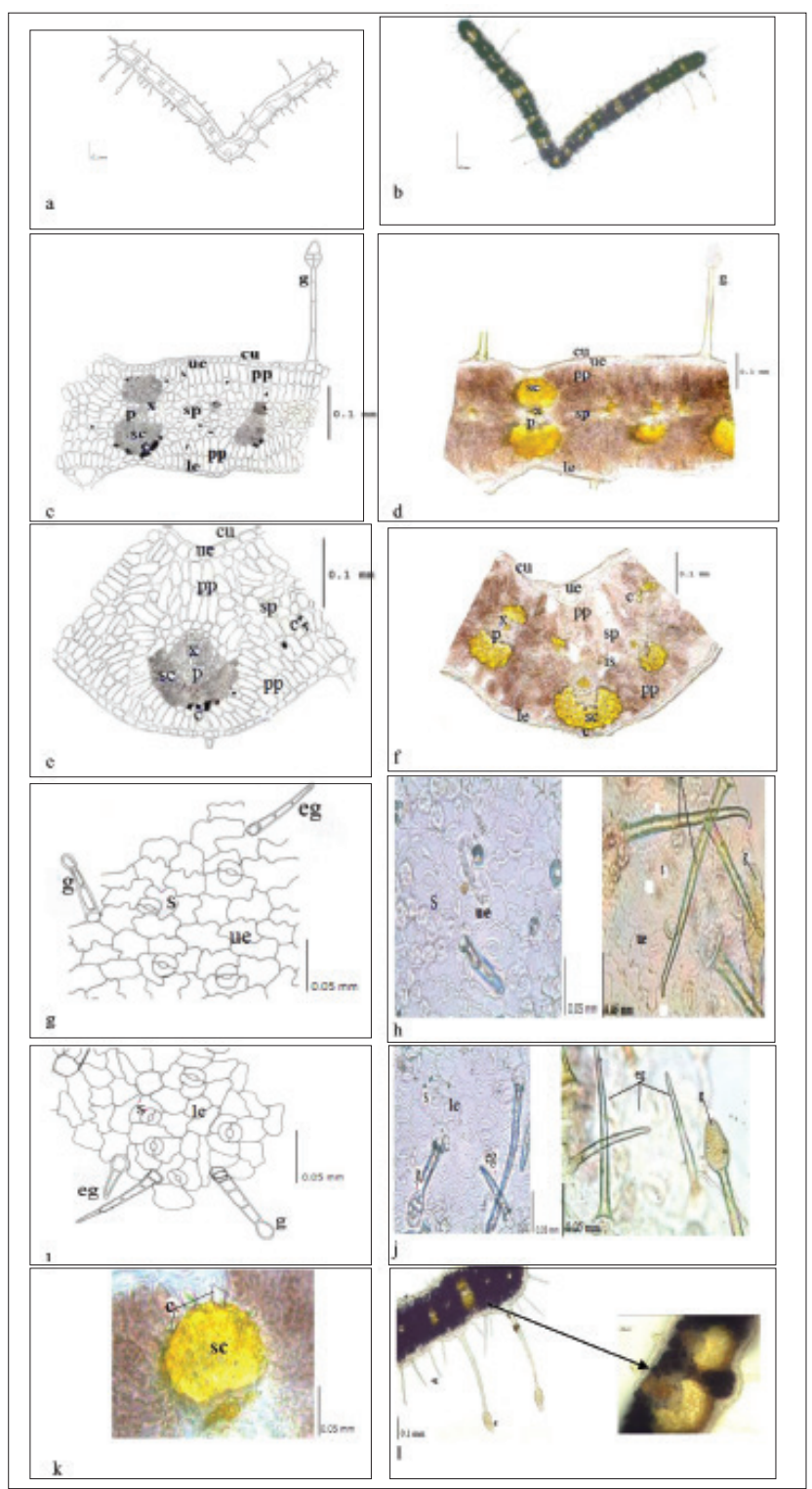

Figure 20 . basiadnata, a,b) Schematic drawing of the cross section of the leaf and photo; c,d) Schematic drawing of transverse section of leaf blade and photo; e,f) Schematic drawing of transverse section of midrib and photo; $\mathrm{g}, \mathrm{h})$ Drawing of upper surface view of leaf and photo;, $\mathrm{j}$ ) Drawing of lower surface view of leaf and photo; k) prismatic crystals in sclerenchyma, l) general view of glandular and eglandular hairs, vascular bundles in mesophyll cu: Cuticle, g: Glandular hair, eg: Eglandular hair, ue: Upper epidermis, c: Crystal, pp: Palisade parenchyma, sp: Spongy parenchyma, sc: Sclerenchyma: p: Phloem, $\mathrm{x}$ : Xylem, s: Stomata, le: Lower epidermis 


\section{Leaf anatomy of O. macrosperma}

\section{Cross section of leaf blade}

The leaf is bifacial. The upper and lower epidermis cells consist of a single layer of square or rectangular-shaped cells with thin walls. The cuticle is thin. Underneath the epidermis there is usually two layers of palisade parenchyma. The spongy parenchyma consists of 4-5 layers of usually isodiametrical cells with few intercellular spaces. Glandular hairs have two types. The first type consists of glandular hairs with a multicellular stalk and a multicellular round-head. The second type consists of a multicellular stalk and a unicellular glandular head. They are sparsely observed relative to the other two species. Rubiaceae type stomata are observed (Figure 3).

\section{Cross section of the midrib}

The upper and lower epidermis cells are square or rectangularshaped cells, and are single-layered with anticlinal walls. The palisade parenchyma cells have a single layer or two layers. The spongy mesophyll with 2-4 layers consists of isodiametric parenchymatous cells with few intercellular spaces. There are sclerenchyma cells which generally surrounded phloem and the xylem is underneath phloem. As in the two other species, solitary crystals with various shapes and sizes (styloids) are observed and frequently form a sheath along the outer boundary of the pericyclic sclerenchyma (Figure 3).

\section{Surface of the lower and upper epidermis}

The lower epidermal cells are similar to those in the upper epidermis. Unlike the upper epidermis, striated cuticle is observed on the lower epidermis. The stomata generally have 3 subsidiary cells. Glandular hairs are sparsely observed on both the upper and lower epidermis (Figure 3).

\section{Stem anatomy of $O$. sessilifolia}

Cross sections from the stems are rounded. The cuticle is thinlayered. The epidermis consists of a single-layer of square or short rectangular cells. Parenchyma cells which have a great number of large and small prismatic crystals are 3-4 lines. The pericycle is end of the parenchyma cells and it is not clear. Sclerenchyma cells which are clustered crescent-shaped and are interconnected with the end portions are arranged in a circle. Crystals are lined up on the sclerenchyma cells individually. The vascular bundles are surrounded with pith and pith rays which are number of 4-6. Phloem is composed of small and irregularly shaped cells. The cambium formes 1 or 2 rows at the start of the xylem. However, it is not very obvious and endodermis layer is not apparent. While the phloem is located on the outer side of the cambium, the xylem is located on its inner side. Pith is formed by rounded and large parenchymatic cells. Also, this part is identified charactersitically by secretory cells in places. The stem has many glandular (a multicellular stalk (1-4 row cells), a multicellular head (1-3 row cells) and fewer eglandular (unicellular and multicellular) hairs. Eglandular trichomes are generally multicellular and long (Figure 4).

\section{Stem anatomy of $O$. basiadnata}

The cross sections of the stem are rounded. The cuticle is thin layered with a crenate margin. The epidermis consists of a single layer of rectangular cells. Parenchyma cells are oval-shaped and have 3-5 lines. The sclerenchyma cells, cluster crystals and vascular bundles (generally 9-11 numbers) resemble those of $O$. sessilifolia. Endodermis layer is not clear. The pith area is narrower than that of $O$. sessilifolia and number of pith rays are 5-7. Eglandular hairs were determined to be more intense than glandular hairs. Also, starch was observed in the parenchyma cells. Locations of the phloem and xylem are similar to 0 . sessilifolia. Pericycle is end of the parenchyma cells, schlerenchymatous, occasionally parenchymatous (Figure 5 ).

\section{Stem anatomy of 0 . macrosperma}

The cross sections of the stem are rounded. The cuticle is thin layered. The epidermis consists of single-layered cells. The parenchyma cells are oval-shaped with 4-6 lines. The sclerenchyma cells, cluster crystals and numbers of the

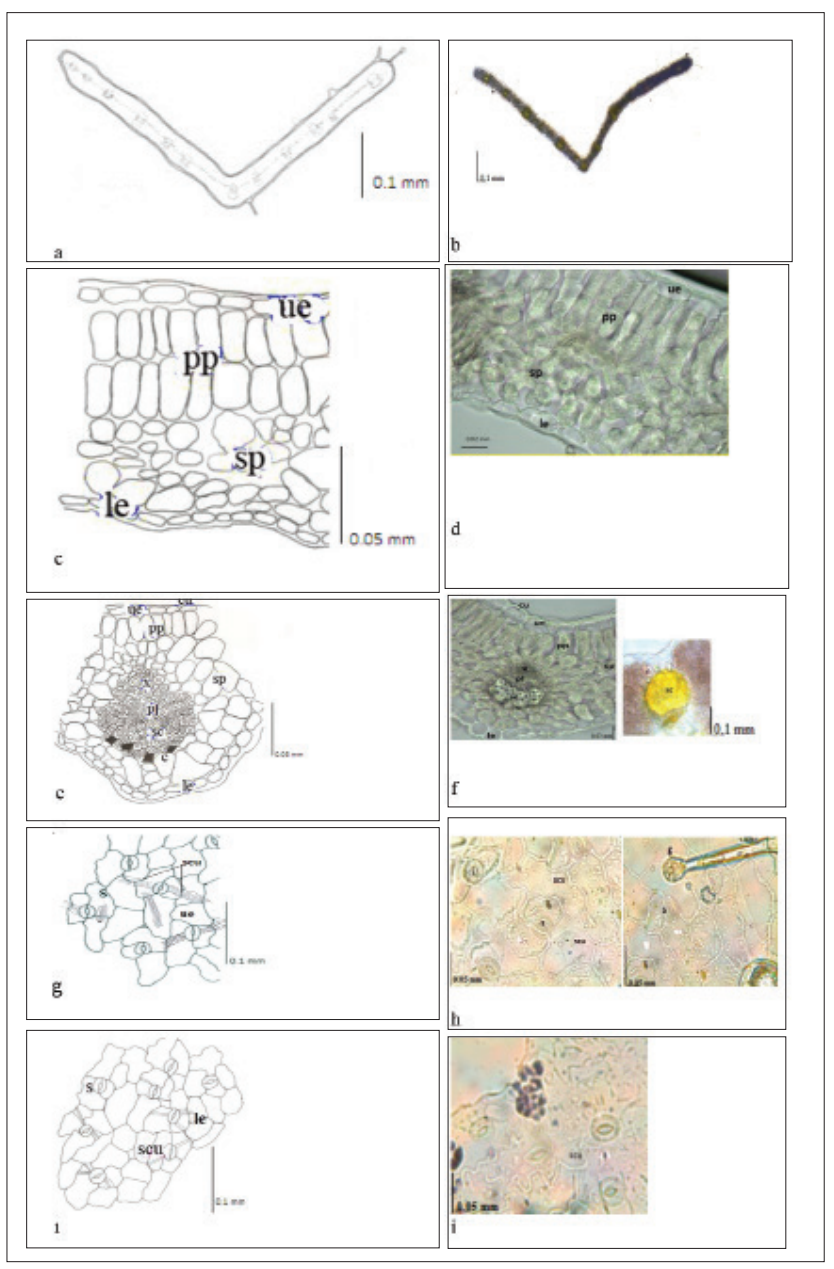

Figure 3. O. macrosperma, $a, b)$ Schematic drawing of the cross section of the leaf and photo; c,d) Schematic drawing of transverse section of leaf blade and photo; e) Schematic drawing of transverse section of midrib; f) midrib photo and prismatic crystals in sclerenchyma; g,h) Drawing of upper surface view of leaf and photo;, j) Drawing of lower surface view of leaf and photo

cu: Cuticle, ue: Upper epidermis, c: Crystal, pp: Palisade parenchyma, sp: Spongy parenchyma, sc: Sclerenchyma, pl: Phloem, x: Xylem, s: Stomata, le: Lower epidermis, g: Glandular hair, ue: Upper epidermis, scu: Striated cuticle 
vascular bundles are generally 9-10 and properties of the phloem and xylem similar to the other two species. Lines of pith rays are commonly 3-4. However, crystals are scarce in comparison to the other two species ( $O$. sessilifolia and $O$. basiadnata). The pith area is narrower than that of 0 . sessilifolia.

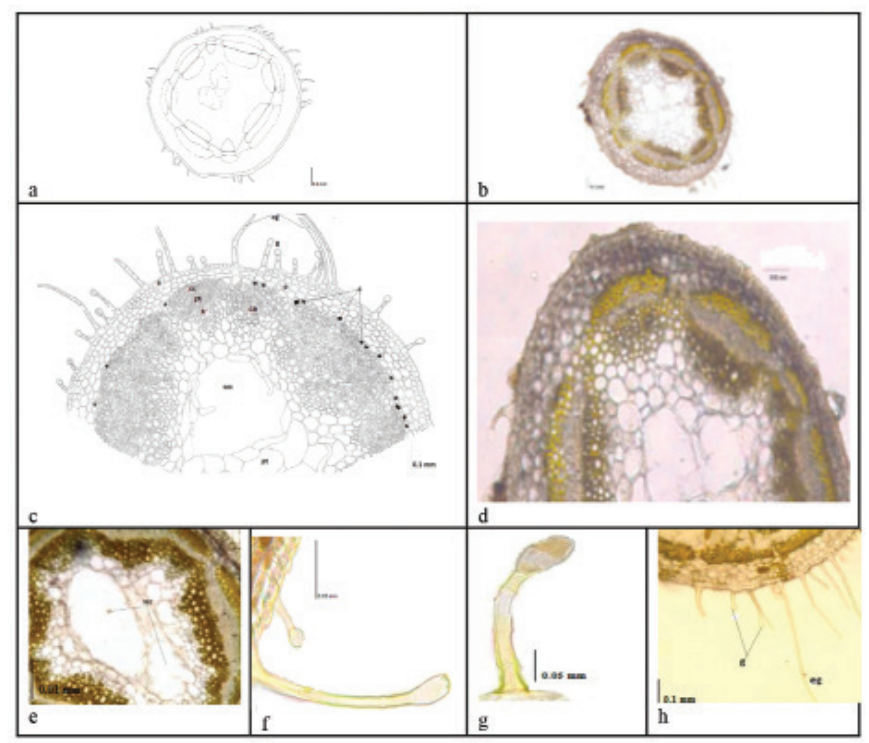

Figure 4. $O$. sessilifolia, transverse section of stem, a,b) Schematic drawing and photo; c,d) Anatomical drawing and photo; e) Secretory cells in pith; $\mathrm{f}, \mathrm{g})$ Glandular hairs; h) Glandular and eglandular hairs

e: Epiderma, p: Parenchyma cells, sc: Sclerenchyma, pl: Phloem, ca: Cambium, x: Xylem, sec: Secretory cells, pt: Pith, g: Glandular hair, eg: Eglandular hair, c: Crystal

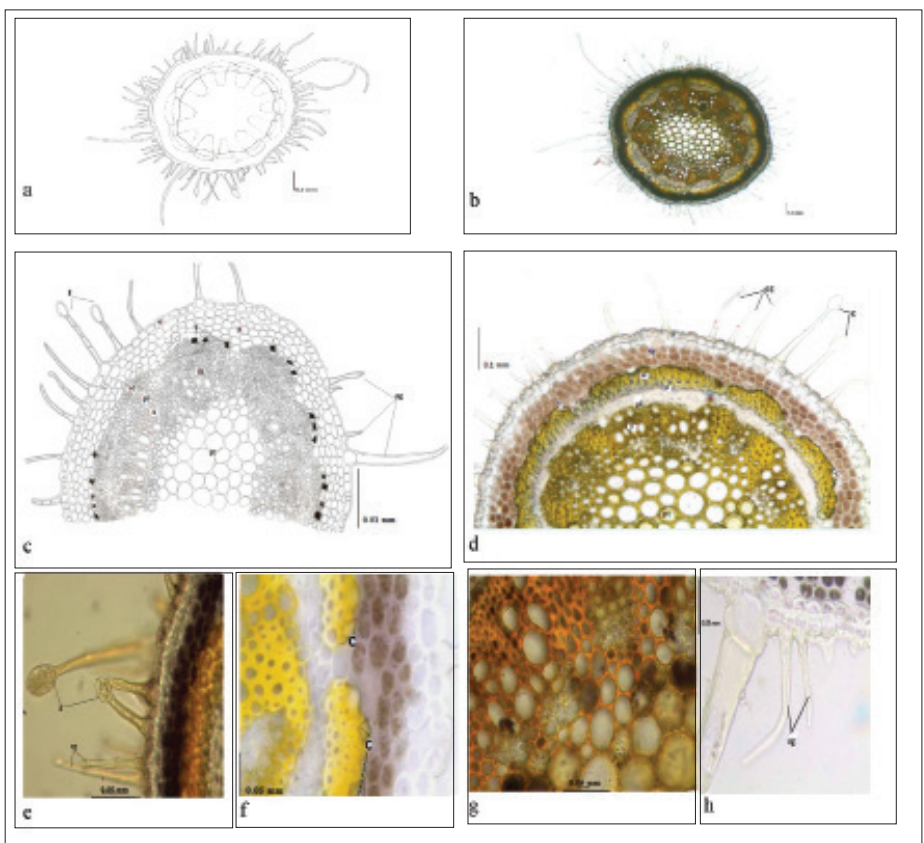

Figure 5. O. basiadnata transverse section of stem, a,b) Schematic drawing and photo; c,d) Anatomical drawing and photo; e) Glandular and eglandular hairs; f) Crystals in sclerenchyma; g) Starch granules in parenchymva cells; h) Eglandular hairs

e: Epiderma, p: Parenchyma cells, sc: Sclerenchyma, pl: Phloem, ca: Cambium, x: Xylem, pt: Pith, g: Glandular hair, eg: Eglandular hair, c: Crystal
Also, secretory cells were detected in the pith 0 . sessilifolia. Glandular and eglandular hairs were seen less frequently than in the other two species. Starch was detected densely in parenchymatic tissue (Figure 6).

In this study, the anatomical properties of three endemic Ononis species were investigated. As it stated in Metcalfe (1965), the three species of Ononis have Rubiaceae type stomata (Figure 1-3). Taia (2004) investigated in leaf characters within tribe Trifolieae (Family Leguminosae). Unlike to our study, it was found that Ononis species (Ononis natrix L., Ononis vaginalis Vahl, Ononis reclinata L., Ononis sicula Guss., Ononis pubescens L., Ononis serrata Forssk.) have diacytic, paracytic, brachyparacytic stomata type. In addition, these species have only multicellular glandular hair. However, in our study, leaf section of 0 . basiadnata was found eglandular hair (Figure 2). The type of vascular bundle in the leaf is similar to that in the stem at three Ononis species. $O$. basiadnata was the most intense in terms of glandular and eglandular hairs (Figure 5, Table 2). The other two species, 0 . sessilifolia and 0 . macrosperma followed it, respectively. The arrangements and type of crystals in stem section were very similar to the leaf anatomy. Furthermore, in stem anatomical studies of $O$. macrosperma and $O$. sessilifolia, the secretory cells in the pith region were detected (Figure 4 , 6, Table 3).

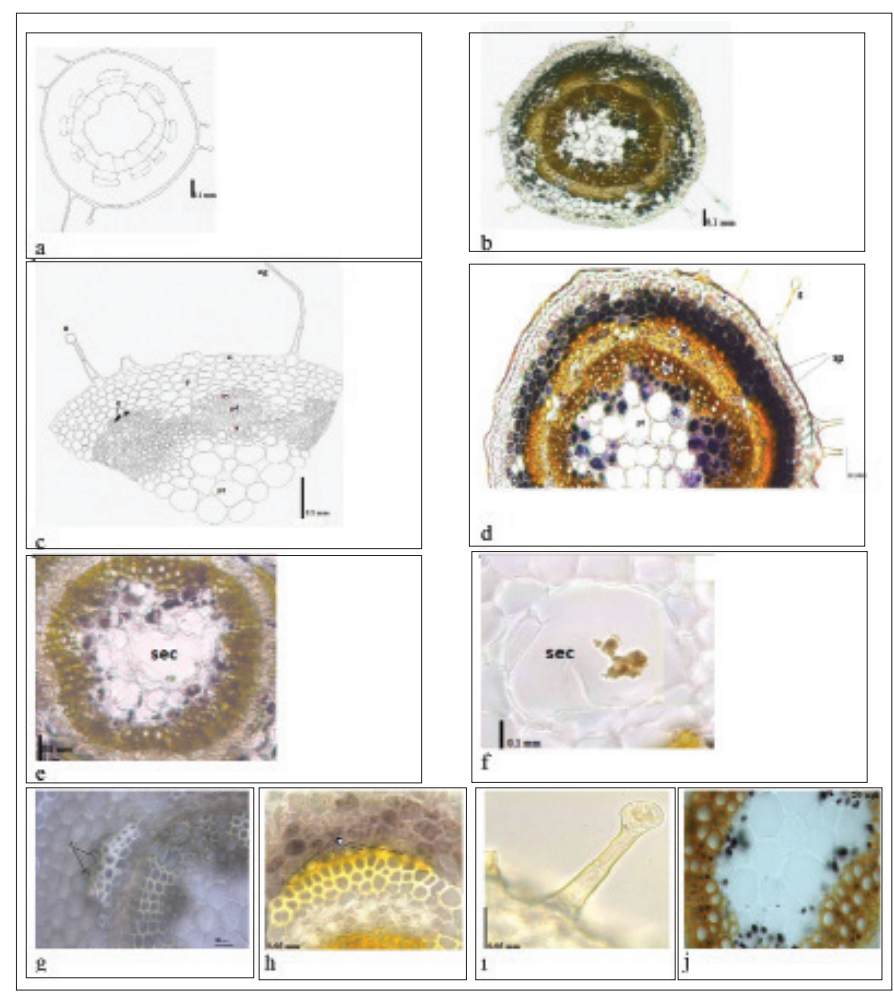

Figure 6. O. macrosperma 0 . macrosperma transverse section of stem, a,b) Schematic drawing and photo; c,d) Anatomical drawing and photo; e, f) Secretory cells in pith; g,h) Crystals in sclerenchyma; I) Glandular hair; j) Starch granules in parenchyma cells

e: Epiderma, p: Parenchyma cells, sc: Sclerenchyma, pl: Phloem, ca: Cambium, x: Xylem, sec: Secretory cells, pt: Pith, g: Glandular hair, eg: Eglandular hair, c: Crystal 
Table 2. Comparison of stem cross sections in 3 Ononis taxa growing in Turkey

\begin{tabular}{|c|c|c|c|c|c|c|c|}
\hline Taxa & $\begin{array}{l}\text { Epidermal } \\
\text { cells }\end{array}$ & $\begin{array}{l}\text { Eglandular } \\
\text { trichomes }\end{array}$ & $\begin{array}{l}\text { Glandular } \\
\text { trichomes }\end{array}$ & $\begin{array}{l}\text { Cortex } \\
\text { parenchyma }\end{array}$ & Pericycle & $\begin{array}{l}\text { Crystals of } \\
\text { calcium oxalate }\end{array}$ & Pith \\
\hline $\begin{array}{l}\text { Ononis } \\
\text { sessilifolia }\end{array}$ & $\begin{array}{l}\text { Square or } \\
\text { rectangular }\end{array}$ & $\begin{array}{l}\text { Usually multi- } \\
\text { cellular (4-5 } \\
\text { cell) and long }\end{array}$ & $\begin{array}{l}\text { Multicellular stalk } \\
\text { and head; multi- } \\
\text { cellular stalk and } \\
\text { unicellular head; } \\
\text { unicellular stalk } \\
\text { and head }\end{array}$ & $\begin{array}{l}\text { 3-5 layers, } \\
\text { cylindrical or } \\
\text { oval cells, starch } \\
(-)\end{array}$ & $\begin{array}{l}\text { End of the } \\
\text { parenchyma cells, } \\
\text { schlerenchymatous, } \\
\text { occasionally } \\
\text { parenchymatous }\end{array}$ & $\begin{array}{l}\text { Individually, } \\
\text { lined up on the } \\
\text { schlerenchyma } \\
\text { cells }\end{array}$ & $\begin{array}{l}\text { Pith area is } \\
\text { wide, rounded } \\
\text { and large } \\
\text { parenchymatic } \\
\text { cells, secretory } \\
\text { cells (+) }\end{array}$ \\
\hline
\end{tabular}

Table 3. Comparison of leaf cross and surface in 3 Ononis taxa growing in Turkey

\begin{tabular}{|c|c|c|c|c|c|c|c|c|}
\hline Taxa & Leaf structure & $\begin{array}{l}\text { Lower and upper } \\
\text { epidermal cells }\end{array}$ & $\begin{array}{l}\text { Eglandular } \\
\text { trichomes }\end{array}$ & $\begin{array}{l}\text { Glandular } \\
\text { trichomes }\end{array}$ & $\begin{array}{l}\text { Crystals of } \\
\text { calcium oxalate }\end{array}$ & $\begin{array}{l}\text { Palisade } \\
\text { parenchyma }\end{array}$ & $\begin{array}{l}\text { Spongy } \\
\text { parenchyma }\end{array}$ & Stomata \\
\hline $\begin{array}{l}\text { Ononis } \\
\text { sessilifolia }\end{array}$ & Monofacial & $\begin{array}{l}\text { The lower } \\
\text { epidermal cells } \\
\text { are similar to } \\
\text { those in the } \\
\text { upper epidermis } \\
\text { which is square } \\
\text { or rectangular, } \\
\text { usually small, } \\
\text { these are covered } \\
\text { with a thin cuticle. }\end{array}$ & - & $\begin{array}{l}\text { Long: } \\
\text { multicellular } \\
\text { stalk and } \\
\text { head, usually } \\
\text { 2-3-celled } \\
\text { head }\end{array}$ & $\begin{array}{l}\text { Solitary } \\
\text { crystals } \\
\text { (Styloids) in } \\
\text { pericyclic } \\
\text { schlerenchyma }\end{array}$ & $\begin{array}{l}\text { Usually } \\
2 \text { layers, } \\
\text { short and } \\
\text { cylindrical, } \\
\text { starch (+) }\end{array}$ & $\begin{array}{l}\text { Isodiametric } \\
\text { parenchymatous } \\
\text { cells, starch (+) }\end{array}$ & $\begin{array}{l}\text { Rubiaceae } \\
\text { type } \\
\text { stomata, } \\
\text { with 3-4 } \\
\text { subsidiary } \\
\text { cells }\end{array}$ \\
\hline $\begin{array}{l}\text { Ononis } \\
\text { basiadnata }\end{array}$ & Monofacial & $\begin{array}{l}\text { The lower } \\
\text { epidermis } \\
\text { (rectangular) cells } \\
\text { are smaller than } \\
\text { the upper ones } \\
\text { (rectangular) and } \\
\text { these are covered } \\
\text { with a thin cuticle. }\end{array}$ & $\begin{array}{l}\text { Densely, } \\
\text { simple, } \\
\text { short: } \\
\text { unicellular; } \\
\text { long: } \\
\text { multicellular }\end{array}$ & $\begin{array}{l}\text { Densely, long: } \\
\text { multicellular } \\
\text { stalk and } \\
\text { head; } \\
\text { multicellular } \\
\text { stalk and } \\
\text { unicellular } \\
\text { head }\end{array}$ & $\begin{array}{l}\text { Solitary } \\
\text { crystals } \\
\text { (Styloids) in } \\
\text { pericyclic } \\
\text { schlerenchyma } \\
\text { generally; and } \\
\text { in mesophyll }\end{array}$ & $\begin{array}{l}\text { Usually } \\
2 \text { layers } \\
\text { and short } \\
\text { cylindrical, } \\
\text { starch (+) }\end{array}$ & $\begin{array}{l}\text { Isodiametric, } \\
\text { starch }(+)\end{array}$ & $\begin{array}{l}\text { Rubiaceae } \\
\text { type } \\
\text { stomata, } \\
\text { with 3-4 } \\
\text { subsidiary } \\
\text { cells }\end{array}$ \\
\hline $\begin{array}{l}\text { Ononis } \\
\text { macrosperma }\end{array}$ & Bifacial & $\begin{array}{l}\text { The lower } \\
\text { epidermal cells } \\
\text { are similar to } \\
\text { those in the upper } \\
\text { epidermis which } \\
\text { is square or } \\
\text { rectangular, } \\
\text { striated cuticle is } \\
\text { seen both upper } \\
\text { and lower surface }\end{array}$ & - & $\begin{array}{l}\text { long: } \\
\text { multicellular } \\
\text { stalk and } \\
\text { multicellular } \\
\text { round-head, } \\
\text { multicellular } \\
\text { stalk and } \\
\text { unicellular } \\
\text { round-head }\end{array}$ & $\begin{array}{l}\text { Solitary } \\
\text { crystals } \\
\text { (Styloids) in } \\
\text { pericyclic } \\
\text { schlerenchyma }\end{array}$ & $\begin{array}{l}\text { Usually } 2 \\
\text { layers and } \\
\text { cylindrical, } \\
\text { starch (+) }\end{array}$ & $\begin{array}{l}\text { Isodiametric, } \\
\text { starch (+) }\end{array}$ & $\begin{array}{l}\text { Rubiaceae } \\
\text { type } \\
\text { stomata, } \\
\text { with } \\
\text { mainly } 3 \\
\text { subsidiary } \\
\text { cells }\end{array}$ \\
\hline
\end{tabular}




\section{CONCLUSION}

This study is original in that, similar and different anatomical features of the three endemic Ononis species growing in Turkey are revealed in detail for the first time. Our investigations showed that anatomical studies also proved to be very important in providing information of taxonomic importance. It is hoped that this study will form a basis for future research on the other Ononis species in Turkey. Furthermore, anatomical studies should be supported by molecular, morphologic and chemical studies.

Conflict of Interest: No conflict of interest was declared by the authors.

\section{REFERENCES}

1. Doyle JJ, Luckow MA. The rest of the iceberg. Legume diversity and evolution in a phylogenetic context. Plant Physiology. 2003;131:900-910.

2. Heywood VH, Brummitt RK, Culham A, Seberg O. Leguminosae (Fabaceae) In: Flowering Plant Families of the World. New York; Firefly Books; 2007:185-188.

3. Davis PH. Flora of the Turkey and the East Aegean Islands. ( $3^{\text {rd }}$ Ed) Edinburgh University Press. London; 1970:375-384.

4. Güner A. A Checklist of the Flora of Turkey (Vascular Plants), Nezahat Gokyigit Botanic Garden Publication. Flora series I; İstanbul; 2012:482484.

5. Evans WC. Trease and Evans Pharmacognosy, WB. $15^{\text {th }}$ ed. Printed in China; 2002:26.
6. Baytop T. Plants with Therapy in Turkey (Past and Present). Nobel Tip Kitabevleri; İstanbul; 1999:251.

7. Langer R, Engler S, Kubelka W. Comparative root anatomy of some perennial taxa of the genus Ononis L. Pharmazie. 1995;50:627-629.

8. Duke JA, Bogenschutz MJ, Ducellier J, Duke PAK. Handbook of Medicinal Herbs. 2th ed. London; 2002.

9. Taia WK. Leaf characters within tribe Trifoliae (Family Leguminosae). J Bio Sci. 2004;7:1463-1472.

10. Baldemir A, Pınar NM, Suludere Z, Coşkun M. Türkiye'de doğal olarak yetișen endemik üç Ononis L. (Fabaceae) türünün polen ve tohum morfolojisi. J Fac Pharm Ankara. 2009;38:89-102.

11. Agullo JC, Juan A, Alonso M, Terrones A, Crespo MB. Taxonomic status of Ononis tridentata (Fabaceae) from Morocco, resolved by multivariate morphometric analyses. Plant Biosyst. 2013;147:645-653.

12. Baldemir A, Coşkun M. Comparative morphological studies on three endemic Ononis L. (Leguminosae) species growing in Turkey. Bio Di Con. 2016;9:82-91.

13. Arıhan O, Güvenç A. Studies on the anatomical structure of stems of willow (Salix L.) species (Salicaceae) growing in Ankara province, Turkey. Turk J Bot. 2011;35:535-551.

14. Ogie-Odia EA, Eseigbe D, llechie MN, Erhabor J, Ogbebor E. Foliar epidermal and phytochemical studies of the grasses Cymbopogon citratus (Stapf.), Axonopus compressus (P. Beauv.) and Eragrostis tremula (S.W. Beauv) in Ekpoma, Edo state, Nigeria. Sci World J. 2010;5:20-25.

15. Metcalfe CR, Chalk L. Anatomy of the dicotyledones. Oxford; Clarendon Press; 1965

16. Çelebioğlu S, Baytop T. A new reagent for microscopial investigation of plant Publication of the Institute of Pharmacognosy. İstanbul; 1949. 